\title{
Micropropagation of Aegle marmelos L. - A Medicinal Tree through Culture of Axillary bud and Shoot tip Explants from In vitro Germinated Seedlings
}

\author{
K. Gandhi ${ }^{1}$, E. Rajesh $^{2}$, S. Saravanan ${ }^{3}$ and M. Elamvaluthi ${ }^{4}$ \\ ${ }^{1}$ Post Graduate and Research Department of Botany, Pachaiyappa's College, Chennai, India \\ ${ }^{2}$ Post Graduate and Research Department of Botany, Pachaiyappa's College, Chennai, India \\ ${ }^{3}$ Post Graduate and Research Department of Botany, Pachaiyappa's College, Chennai, India \\ ${ }^{4}$ Post Graduate and Research Department of Botany, Pachaiyappa's College, Chennai, India
}

*Corresponding authors email: sstc1965@yahoo.co.in

Available online at: www.isroset.org

Received: 26/May/2018, Revised: 05/Jun/2018, Accepted: 19/Jun/2018, Online: 30/Jun/ 2018

\begin{abstract}
Aegle marmelos L. is an important medicinal tree and it is commonly known as bael tree. In the present study, an efficient and improved plant regeneration protocol was developed for A. marmelos. Axillary bud and shoot tips from the in vitro germinated seedlings of A. marmelos were used as explants. Murashige and Skoog (MS) medium used as basal medium and MS medium devoid of any growth regulators was used for the in vitro germination of seeds. MS medium supplemented with different concentration and combinations of growth regulators such as 6-benzyl aminopurine (BAP), indole-3- butyric acid (IBA) and $\alpha$-naphthaleneacetic acid (NAA) were employed. The medium fortified with $11.11 \mu \mathrm{M} / \mathrm{L}$ of BAP and $1.07 \mu \mathrm{M} / \mathrm{L}$ of NAA was found to be effective one for the initiation and multiplication of shoots with highest mean number of shoots (24.20 $\pm 3.85)$ and maximum mean length of the shoots $(6.02 \pm 0.64)$. Half strength MS basal medium supplemented with $14.76 \mu \mathrm{M} / \mathrm{L}$ of IBA was found to be effective one for rapid and maximum root induction per micro shoot. The well rooted in vitro raised plants were successfully hardened house with survival rate of $80 \%$. This effective and improved protocol may be useful for the large scale production of this plant.
\end{abstract}

Keywords - Micropropagation, Aegle marmelos, In vitro seed germination, Axillary buds, Shoot tip

\section{INTRODUCTION}

Indian bael tree scientifically called as Aegle marmelos (L.), belongs to the family Rutaceae, has been widely used in Indian medicinal systems due to its various medicinal values [1]. It has also known by many other common names like bengal quince, golden apple, Japanese bitter orange, stone apple or wood apple. It is a highly reputed ayurvedic medicinal tree with rich source of bio chemical compounds like Skimmianine, Aegeline, Lupeol, Cineol, Citral, Citronella, Cuminaldehyde, Eugenol, Marmesinine, Fagarine, Marmelosin, Luvangetin, Aurapten, Psoralen, Marmelide, Tannin, alkaloids, coumarins, steroids, polysaccharides, carotenoids, phenolic compounds etc., [2, 3]). In India, Bael tree is considered to be very sacred by Hindus. The history of this tree has been traced to Vedic period (2000 B.C - 800 B.C). The mention of bael fruit has been made in one of the oldest books in the Indian Vedas called Yajurveda. The bael tree has great mythological significance and abundant in the vicinity of traditional Hindu Temples especially in Shiva temples. This medium sized tree is indigenous to dry forests on hills and plains of India.
Almost all the parts of this tree are used to treat aliments. The roots are used to cure diarrhoea, dysentery, and dyspepsia. The leaf is used for opthalmia, diabetes and asthmatic complains. Unripe fruit is useful for treating diarrhoea, dysentery, and stomachalgia. The aqueous extracts of the stem and root bark are used to treat malaria, fever, jaundice, and skin disease such as ulcers, utricaria, and eczema. Chronic diarrhoea or dysentery responds well to bilva this therapeutic effect being included in the British pharmacopoeia [4-6]. Various bio activities has been reported such as anti diabetic activity [7], hepatoprotective activity [8], antimicrobial activity [9], analgesic anti-inflammatory and antipyretic activity [10], antifungal activity [11], anticancer activity [12], radioprotective activity [13], antiulcer activity [14], anti thyroid activity [15], insecticidal activity [16], antilipid peroxidative activity [17] and antioxidant property [18]. Plant tissue culture is a proven technique to produce millions of identical plants under aseptic condition. It is not only reducing the time and space but also gives greater output and allows further augmentation of elite disease free propagules.

The commercial production of this tree is restricted due to the shortage of desirable planting material or due to various other 
factors like urban development, deforestation, and indiscriminate collection of plants. Tissue culture can play an important role in rapid propagation of new cultivars of this medicinal tree. Plant tissue culture techniques are becoming increasingly popular as alternative means of plant vegetative propagation. The production of millions of plants through direct and indirect, suspension cultures and embryogenesis can be achieved. Medicinal plants and herbs are one of the crucial components as far as the contribution of biodiversity to society is concerned. Many researchers have developed mass propagation technique for this medicinal tree using various explants like nodal segments [19-23], cotyledon tissues [24-26], leaf primordial [27], fertilized ovules of immature fruits [28]. The mass propagation technique using seeds via embryo culture of this medicinal tree is very limited. Hence, the main objective of this study was to standardize the micropropagation protocol for A. marmelos - an important medicinal tree and to check the suitability of axillary bud and shoot tip from the in vitro germinated seedlings as an explants for the plant regenaration.

\section{MATERIALS AND METHODS}

\section{Source and preparation of explants}

The healthy ripped fruits of A.marmelos were collected from Lord Shiva temple Koimbedu, Chennai, Tamilnadu, India. The seeds were separated from the fruit and rinsed with tween-20 solution and washed with running tap water and then immersed in to $70 \%$ ethanol for 10 minutes. The washed seeds were surface sterilized with $0.1 \%$ of $(\mathrm{w} / \mathrm{v})$ of disinfectant mercuric chloride $\left(\mathrm{HgCl}_{2}\right)$ for 5-10 min. After the surface sterilization the seeds were rinsed 3 times with sterile water to remove the traces of $\mathrm{HgCl}_{2}$ adhering to the surface of the seeds. The seed coat was removed with the help of sterile blade in aseptic condition under the Laminar air flow chamber (LAF) without damaging of cotyledons and embryos. The excised seeds with embryo were subjected to in vitro seed germination on Murashige and Skoog (MS) [29] basal medium supplemented with $3 \%$ of sucrose without growth regulators. All the media used were autoclaved for 20 minutes at $121^{\circ} \mathrm{C}$ and $15 \mathrm{psi}$ of pressure and the $\mathrm{pH}$ of the media were adjusted to 5.8. The nodal regions and shoot tips from in vitro germinated seedlings were excised and were used as explant for this investigation.

\section{Inoculation and culture condition}

The explants such as axillary buds and shoot tips from in vitro germinated seedlings were excised and size was about $0.5-1.0$ $\mathrm{cm}$ length. The explants were used without surface sterilization and they were inoculated on MS basal medium fortified with different concentrations and combinations of plant growth regulators. The nine different combination (MS1 toMS-9) of growth regulators such as 6-benzyl amino purine (BAP) and of $\alpha$-Napthalne acetic acid (NAA) were used to study their effect on multiplication of shoots and six different concentrations (MS-10 to MS-15) Indole 3-butyric acid (IBA) $0.2-1.00 \mathrm{mg} / \mathrm{L}$ was used to study their effect on root induction.

All the cultures were incubated under the temperature of $25 \pm$ $2^{\circ} \mathrm{C}$ and the light intensity of $2000-4000$ Lux. The photoperiod regime for cultures was $16 \mathrm{hr}$ light and $8 \mathrm{hr}$ dark and the relative humidity was maintained between $50-60 \%$.

\section{Multiple shoot initiation and subculture}

Axillary bud and shoot tip explants were inoculated in each culture bottles containing MS medium fortified with nine different combinations (MS-1 toMS-9) of growth regulators such as 6-benzyl amino purine (BAP 2.22-11.11 $\mu \mathrm{M} / \mathrm{L}$ ) and of $\alpha$-Napthalne acetic acid (NAA 0.54 and $1.07 \mu \mathrm{M} / \mathrm{L}$ ) were used to study their effect on multiple shoot induction. MS medium without any growth regulators served as control.

The young multiple shoots initiated were removed and sub cultured on fresh culture bottles containing MS medium fortified different combinations of growth regulators for further multiplication. The cultures were observed regularly and the results were recorded for every sub culture. The number and the length of shoots were recorded in 30 days old culture.

\section{Root induction and hardening}

After the multiplication phase, the in vitro developed shoots were excised ( $3-4 \mathrm{~cm}$ in length) and transferred to rooting medium. Indole 3-butyric acid (IBA) was used to study their effect on rooting. For the root induction, the medium is constituted with half and full strength of MS basal medium supplemented with different concentrations of IBA (4.92 $19.68 \mu \mathrm{M} / \mathrm{L})$. The number and the length of roots were recorded to assess the best treatment.

The well developed and healthy plant lets with roots were taken out and washed thoroughly and then transferred to protrays containing the primary hardening mixtures of sand and vermiculite (1:1) under the green house conditions.

\section{Statistical Analysis}

The collected data were analyzed by analysis of variance (ANOVA) followed by Tuky's HSD test values to compare the significant differences among means at $5 \%$ level of significance. All the data were expressed in the Mean \pm Standard Deviation.

\section{RESULTS AND DISCUSSION}

\section{In vitro seed germination}

The sterilized and excised seeds were inoculated on MS basal medium (MS-0) without any growth regulator in culture room. Cotyledons were opened completely within five days and the cotyledons were turned in to green colour (Figure 1a). The induction of plumule and radical was noticed after seven days of inoculation. The plumule elongated with leaf primordium, where as the radical did not elongate. The shoot grew to the length of 3.5 to $4.0 \mathrm{~cm}$ within fifteen days of incubation. After 25 days, the cultures produced well 
developed shoots with 3 - 4 leaf per shoot and the cotyledons were remain fresh without shrinking (Figure 1b). The axillary bud and shoot tip explants were selected from these in vitro grown seedlings and it was used for initiation of shoots.

\section{Initiation of shoots}

The explants were inoculated on MS basal medium supplemented with different concentrations of BAP (2.22, $4.43,6.65,8.87$ and $11.11 \mu \mathrm{M} / \mathrm{L})$ and some in combination with NAA $(0.54$ and $1.07 \mu \mathrm{M} / \mathrm{L})$. All the media (MS-1 to MS9) responded to initiation of shoots but the percentage of shoot induction, number and length of shoots were varied (Table 1). The shoot induction was poor on the MS-1 medium supplemented with $2.22 \mu \mathrm{M} / \mathrm{L}$ of BAP alone which showed the induction percentage of $15.17 \pm 1.65 \%$. The medium fortified with $11.11 \mu \mathrm{M} / \mathrm{L}$ of BAP and $1.07 \mu \mathrm{M} / \mathrm{L}$ of NAA (MS-9) were yielded highest percentage $(81.40 \pm 8.70 \%)$ of shoot induction and also produced highest mean number of shoot buds per explant $(6.00 \pm 1.63)$ with mean shoot length of $2.31 \pm 0.71 \mathrm{~cm}$ (Figure 1c). This result were akin to the results of Raghu et al., [30], who reported that, an in vitro clonal propagation technique of this endangered medicinal tree by enhanced axillary shoot proliferation from mature single node in which they obtained an average of 6.2 shoots per explant.

\section{Multiplication of shoots}

Shoot multiplication is the second phase of in vitro micropropagation. In this phase the young shoots were subcultured on to the fresh medium with same composition. The multiplication of shoots was occurred in all media combinations but with varied response in terms of number of shoots (Table 1). The maximum percentage of multiplication $(83.70 \pm 9.59)$ was noticed on the medium fortified with $11.11 \mu \mathrm{M} / \mathrm{L}$ of BAP and $1.07 \mu \mathrm{M} / \mathrm{L}$ of NAA (MS-9). This medium were also produced the highest number of $(24.20 \pm$ 3.85 ) shoots with mean length of $6.02 \pm 0.64 \mathrm{~cm}$ (Figure 1d). Gupta Sandhya et al., [31] had reported that the BAP of 0.5 $\mathrm{mg} / \mathrm{L}$ along with IAA of $0.1 \mathrm{mg} / \mathrm{L}$ was best for shoot multiplication of bael tree. Ajit kumar and Seeni [22] had also achieved Rapid clonal multiplication of $A$. marmelos with by enhanced axillary bud proliferation and they found nodal explants responded most favourably at low BAP (0.05- 0.1 $\mathrm{mg} / \mathrm{L}$ ) but in our study it is clear that our explants responded most favourably in MS-9 containing combination of BAP$11.11 \mu \mathrm{M} / \mathrm{L}$ and NAA-1.07 $\mu \mathrm{M} / \mathrm{L}$. Hence, it was found to be the suitable one for in terms of initiation and multiplication of shoots successfully. The concentration of BAP and NAA used significantly affected the percentage of shoot regeneration, number and shoot length. In the present study, BAP fortified medium showed comparatively less effects on initiation and multiplication of shoots than that of the medium enriched with the combination of BAP and NAA and the similar effect also reported in Gentiana kurroo [32]; Mentha arvensis [33].

\section{Root induction and hardening}

The thirty days old well developed shoots were excised (3$4 \mathrm{~cm}$ in length) and transferred to rooting medium. The root induction was responded in all media combinations. Among the various media combinations, full-strength MS-10 with IBA $-4.92 \mu \mathrm{M} / \mathrm{L}$ showed poor rooting response $(23.80 \pm$ $4.49 \%$ ) with mean number of $1.35 \pm 0.52$ roots with the mean length of $3.46 \pm 0.53$ (Table 2). The half strength MS medium supplemented with $19.68 \mu \mathrm{M} / \mathrm{L}$ of IBA (MS-15) was responded maximum percentage of root induction $(84.00 \pm$ $6.14)$ and also produced highest mean number of roots $(4.5 \pm$ 1.08 ) per shoot with mean length of $5.45 \pm 0.83 \mathrm{~cm}$ (Table 2; Figure 1e). IAA of $0.1 \mathrm{mg} / \mathrm{L}$ was effective for rooting in Aegel marmelos [31], But there In vitro rooting was inconsistent compared to our result and our survival rate of plantlets was higher than the Raghu et al., [30] reports $(83.9 \%)$. Whereas the media combinations MS-11 and MS-13 fortified with (1/2 MS + IBA 4.92 and $9.84 \mu \mathrm{M} / \mathrm{L})$ showed moderate percentage of root induction. The morphology of all the roots appeared white in colour but later it turned in to light green in colour. It was noticed that there was no branches on the produced roots in all combinations. Ajit kumar and Seeni [22] were also observed shoot cuttings were best rooted in half-strength MS medium with $0.5 \mathrm{mg} / \mathrm{L}$ of IAA $(70 \%)$ or $10.0 \mathrm{mg} / \mathrm{L}$ indole-3-butyric acid (90\%). In our study we found the best rooting was achieved in the halfstrength MS medium with IBA of $19.68 \mu \mathrm{M} / \mathrm{L}$. The half strength medium was significantly efficient than the full strength MS basal medium for root induction.

The well rooted in vitro developed plantlets were transferred to protrays containing hardening mixture of sand and vermiculite in the ratio of 1:1 for primary hardening under the green house condition with $80 \%$ of survival rate. In the present study, micropropagation protocol was achieved up to primary hardening phase. Singh Sugandha [34] reported that the conventional plant propogation method for woody trees are often difficult and slow because of high levels of heterozygosity and the long generation time between successive crosses. Plant tissue culture is the science and art of growing plantlets from a single plant cell, tissue, or organ using artificial media. The role of plant tissue culture is invaluable in the conservation and rejuvenation of endangered medicinal woody plants.

\section{CONCLUSION}

The standardized protocol of this study could be effective for rapid multiplication and reintroduction of this important endangered woody medicinal tree to the field. The explants axillary bud and shoot tip from in vitro germinated seedlings were found to be suitable for successful micropropagation. However it is necessary to use molecular marker to check the genetic fidelity of this in vitro grown A. marmelos species with the mother plant used to validate its true to type. Further studies will be on the genetic fidelity analysis using advanced molecular markers. 


\section{ACKNOWLEDGEMENT}

The authors are grateful to the Department of Science and Technology, Government of India, New Delhi for awarding INSPIRE fellowship (Grant no: DST/INSPIRE/2010/(178) to pursuit this study.

\section{REFERENCES}

[1] A. Kar, B. K. Choudhry, N. G. Bandhopadhyay, "Comparative evaluation of hypoglycemic activity of some Indian medicinal plants in alloxan diabetic rats" $J$ Ethnopharmacol. Vol.84, pp.105108. 2003.

[2] P. Maity, D, Hansda, U. Bandyopadhyay, D.K. Mishra. "Biological activities of crude extracts of chemical constituents of Bael, Aegle marmelos (L.) Corr." Indian Journal of Experimental Biology, Vol.47, pp. 849-861. 2009.

[3] Tiwari Bhrigu Narayan, Khatri Pankaj, Ali Julfikar; Soni, M L; Pael Rakesh, Tissue culture of endangered Bael tree (Aegle marmelos) : A Rewiew. J. Adv. Sci. Res, Vol.1, Issuse.2, pp. 34-40. 2010.

[4] H. Panda, "Medicinal Plants: Cultivation and Their Uses", National Institute of Industrial Research. India, 2002

[5] H.K. Bakhru, "Foods That Heal", Orient Paperbacks, India, 1995.

[6] Saswati Parichha, "Bael (Aegle Marmelos): Nature's Most Natural Medicinal Fruit", Orissa Review. 2004

[7] S. Upadhya, K.K. Shanbhag, G. Suneetha, B. M. Naidu, S. Upadhya, "A study of hypoglycemic and antioxidant activity of Aegle marmelos in alloxan induced diabetic rats", Ind. J. Physiol. Pharmacol., Vol.48, pp. 476-480. 2004.

[8] V, Singanan, M, Singanan, H. Begum, "The hepatoprotective effect of bael leaves (Aegle marmelos) in alcohol induced liver injury in albino rats"; International Journal of Science \& Technology; Vol.2, Issuse.2, pp. 83-92. 2007.

[9] V.L, Maheshwari, P.V. Joshi, R. H. Patil, "In vitro anti diarrhoeal activity and toxicity profile of Aegle marmelos Correa ex. Roxb. dried fruit pulp", Natural Product Radiance; Vol. 8, Issuse.5, pp. 498-502. 2009

[10] V, Arul, S. Miyazaki, R. Dhananjayan. "Studies on the antiinflammatory, antipyretic and analgesic properties of the leaves of Aegle marmelos Corr.", Journal of Ethnopharmacology, Vol.96, Issuse.4, pp.159-163. 2005.

[11] R. H. Patil, B. Chaudhary, S. Settipalli, "Antifungal and Antiaflatoxigenic activity of Aegle marmelos Linn.", Pharmacognosy Journol, Vol.1, pp. 4. 2009.

[12] V, Latica, L. Costa,"Evaluation of anticancer potential used in Bangladeshi folk medicine", J. Ethnopharmacol., 99(1), pp. 21-38. 2005.

[13] G. C. Jagetia, Venkatesh, P. "Radioprotection by oral administration of Aegle marmelos (L.) Correa in vivo." J. Environ. Pathol. Toxicol. Oncol., Vol.24, pp. 315-332. 2005.

[14] R. K, Goel, R. N. Maiti, M. Manickam, A. B. Ray.”Antiulcer activity of naturally occurring pyrano cumarin and isocoumarins and their effect on prostanoid synthesis using human colonic mucosa", Indian J Exp Biol. Vol.35, pp. 1080-83. 1997.

[15] S. Panda, A, Kar. "Evaluation of the antithyroid, antioxidative and antihyperglycemic activity of scopoletin from Aegle marmelos leaves in hyperthyroid rats", Phytother Res. Vol. 20, Issuse. 12, pp.1103-5. 2006

[16] R. Kumar, A. Kumar, C.S. Prasa, N. K. Dubey, R. Samant, "Insecticidal activity Aegle marmelos (L.) Correa essential oil against four stored grain insect pests" Internet journal of food safety, Vol.10, pp.39-49. 2008.
[17] N. Kamalakkannan, S.M.P. Prince, "Effect of Aegle marmelos Correa. (Bael) fruit extract on tissue antioxidants in streptozotocin diabetic rats". Ind. J. Exp. Biol., Vol.41, pp.1285-1288. 2003.

[18] V. Vimal, T. Devaki, "Linear furanocoumarin protects rat myocardium against lipidperoxidation and membrane damage during experimental myocardial injury". Biomed. Pharmacother, Vol.58, pp.393-400. 2004.

[19] Rajesh Pati, Ramesh Chandra, Ugam Kumari Chauhan, Maneesh Mishra , Navin Srivastava, In vitro clonal propagation of bael (Aegle marmelos Corr.) CV. CISH- B1 through enhanced axillary branching. Physiol. Mol. Biol. Plants; Vol.14, Issuse. 4: 337- 346. 2008.

[20] M.R. Islam, S. Zaman, K. Nasirujjaman, "Regeneration of plantlets from node- derived callus in Aegle marmelos Corr". Biotechnology Vol.6, Issuse.1: 72-75. 2007.

[21] Rekha Warrier, Jasmine Viji, P. Priyadharshini, "In vitro propagation of Aegle marmelos L.( Corr.) from Mature trees through enhanced axillary branching", Asian J. Exp. Biol. Sci. Vol 1 (3): 669-676. 2010.

[22] D. Ajithkumar, S, Seeni. "Rapid clonal multiplication through in vitro axillary shoot proliferation of Aegle marmelos (L). Corr., a medicinal tree", Plant cell Reports. Vol.17: 422-426. 1998.

[23] Kuldeep Yadav, Narender Singh, In vitro propagation and biochemical analysis of field established wood apple (Aegle marmelos L.) Analele universitatii din Oradea-Fascicula Biologie Tom. Xviii. Issue: 1. pp. 23-28. 2011.

[24] P. Puhan, M. Thirunavoukkarasu, "Direct organogenesis of Aegle marmelos ( L.) Corr. from cotyledon explants", African Journal of Biotechnology., Vol.10, Issuse. 82, pp. 18986- 18990, 2011.

[25] R. Das, M. F. Hasan, M .S. Rahman, M .H. Rashid, M. Rahman, "Study on In vitro propagation through multiple shoot proliferation in wood apple (Aegle marmelos L.)", Int. J. Sustain. Crop prod. Vol.3, Issuse. 6: 16- 20. 2008.

[26] D.P. Prematilake, H.A.S. Nilmini, Kudagamage, "Establishment of an in vitro plant regeneration system for Aegle marmelos (L.) Corr. via organogenic callus culture. Cey. J. Sci 9 Bio . Sci. Vol.35, Issuse.1: 87-90. 2006.

[27] T. Ramanathan, K. Satyavani, S. Gurudeeban, In vitro plant regeneration from leaf primordial of gum bearing tree Aegle marmelos. E-International Scientific Research Journal. ISSN: 2094- 1749 vol.3, Issue.1. 2011.

[28] M. Hossain, M.R. Karim, R. Islam, O.I. Joarder. Plant regeneration from nucellar tissues of Aegle marmelos through organogenesis. Plant cell ,Tissue and organ Culture. Vol.34, Issue 2, pp 199- 203. 1993.

[29] T. Murashige , F. Skoog, A revised medium for rapid growth and bioassays with tobacco tissue cultures. Physiol. Plant, Vol.15: 473497. 1962

[30] A.V. Ragu, S.P. Geetha, Martin Gerald, Balachandran Indira, P.N Ravindran, K.V. Mohan, " An Improved of Micropropagation Protocol for Bael- A Vulnerable Medicinal Tree. Res J. Bot. Vol.2: 186-194. 2007.

[31] Gupta Sandhya, Chauhan Devendra, Bala Manju, Indian Journal of Horticulture: Vol.65, Issue.1. 2008.

[32] N. Sharma, K. P. S. Chandel, Anderson Paul. "In vitro propagation of Gentiana kurroo and indigenous threatened plant of medicinal importance". Plant cell Tissue and organ culture. Vol.34:307-309. 1993.

[33] A.K. Shasany, P. S. Suman, Khanujia, S. Dhawan, Usha Yadav, Srikant Sharma, Sushil Kumar. High regenerative nature of Mentha arvensis inter nodes. J. BioSci. 23: 641-646. 1998.

[34] Singh Sugandha "Callus Induction, Anti Microbial Screening and in Vitro Plantlet Regeneration of Adansonia Digitata L.: Anendangered Medicinal Tree", International Journal of Scientific Research in Biological Sciences,. Vol.2, Issue.5, pp.10-16, 2015. 


\section{AUTHORS PROFILE}

Dr. K. Gandhi pursed B.Sc., M.Sc., M.Phil., and Ph.D., Botany from Pachaiyappa's College affiliated to University of Madras, Chennai, Tamil Nadu, India. He pursed B.Ed from Meston College of Education, University of Madras. He has been awarded K. Kamarajar Medal for securing First rank in M.Sc from University of Madras and Prof. R. Kalyanasundaram memorial Prize for Best Ph.D Thesis from University of Madras. He has qualified

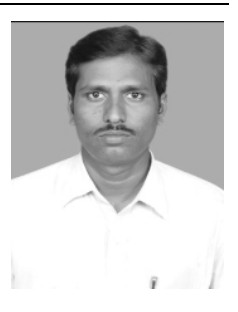
State Level Eligibility Test (SLET) for Lecturership. He was a DSTINSPIRE Fellow and has 9 years of research experience. He has published 4 research papers in reputed journals. His area of research work is Plant Tissue culture and biotechnology.

Mr. E. Rajesh pursed B.Sc., M.Sc., M.Phil., Botany from Pachaiyappa's College affiliated to University of Madras, Chennai, Tamil Nadu India. He pursed B.Ed from Institute for Advanced Studies in Education, Saidapet, India. He is pursuing Ph.D., research in Pachaiyappa's College affiliated to University of Madras, India. He has been awarded K. Kamarajar Medal for securing First rank in

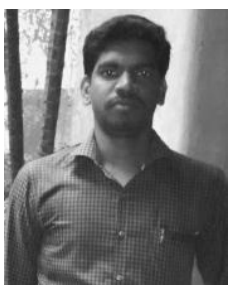
M.Sc from University of Madras. His main research work focuses on Ethanobotany and conservartion of medicinal plants using tissue culture.

Dr. S. Saravanan pursed B.Sc. from Kandaswamy Kandar's College, Velur, Namakkal District, India. M.Sc., from A.A. Govt., Arts College, Namakkal District, India. M.Phil., and Ph.D., from Pachaiyappa's College affiliated to University of Madras, Chennai, India. He pursed B.Ed., Biological Science from Govt., College of Education, Pudhukottai District. India. $\mathrm{He}$ is

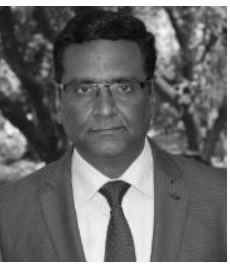
currently working as an Associate Professor in Post Graduate and Research Department of Botany, Pachaiyappa's College, Chennai, India. $\mathrm{He}$ worked as an Assistant Manager and Head of the Production Center in $\mathrm{M} / \mathrm{s}$.Kothari Biotech Ltd., Tissue culture production Center, Bangalore and also worked as a Scientist in M/s. Shakthi Golden Salts, (Chemfab Alkalies Pvt., Ltd.,) Pondicherry. He underwent training in the Ginosar tissue culture nurseries and Kibutz Ginosar which are situated in the Israel for the Commercial Micropropagation technique. His research mainly concentrated on the development of protocols for the micropropagation of various economically important plants belonging to various sectors viz., agriculture, Horticulture, Essential oils, Medicinal and aromatics. He has 18 years of teaching experience and 29 years of research experience.

Dr. M. Elamvaluthi pursed B.Sc. from Guru Nanak College in 1998, M.Sc., Ph.D. from Centre for Advanced Studies in Botany (CAS), University of Madras, in 2001 \& 2006. He is currently working as an Assistant Professor in Post Graduate and Research Department of Botany, Pachaiyappa's College, Chennai, India. $\mathrm{He}$ worked as a Research Scientist in Golden Jubilee Biotech Park for Women Society at

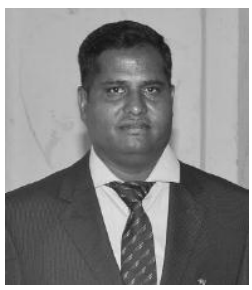
Chennai (SIPCOT-IT Park, Siruseri), India, he also worked as a Research Associate in a well trusted pain reliever pharmaceutical company (Amrutanjan Limited) in India. He has published more than 20 research papers in reputed National and international journals. His main research work focuses on Micropropagation, Mycorrhization and Phytochemistry of Medicinal Plants. He has 5 years of teaching experience and 18 years of research experience. 


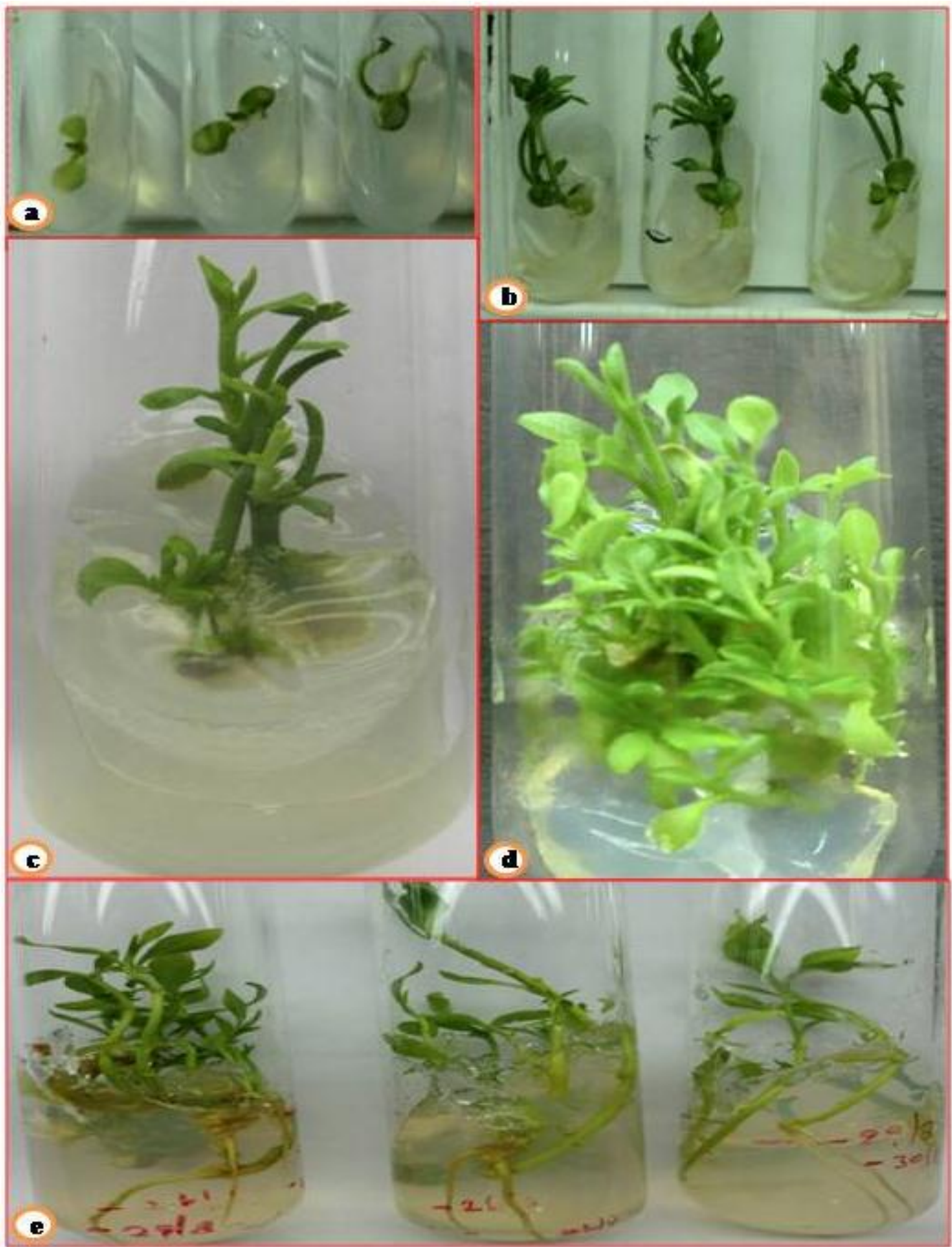

Figure 1: Different stages of micropropagation of Aegel marmelos.

a- Seeds are start germinate and cotyledons opened and turned in to green colour after 5 days of inoculation. b- In vitro germinated 25 days old seedlings. c- initiatiated shoots. d- Multiple shoots 30 days after subculture. e- Rooting stage. 
Table 1: Effect of plant growth regulators on initiation and multiplication of shoots

\begin{tabular}{|c|c|c|c|c|c|c|c|c|}
\hline \multirow[t]{2}{*}{ Medium } & \multicolumn{2}{|c|}{$\begin{array}{c}\text { Plant growth } \\
\text { regulators }\end{array}$} & \multicolumn{3}{|c|}{ Initiation of shoots } & \multicolumn{3}{|c|}{ Multiplication of shoots } \\
\hline & $\begin{array}{c}\text { BAP } \\
(\mu \mathbf{M} / \mathbf{L})\end{array}$ & $\begin{array}{l}\text { NAA } \\
(\mu \mathrm{M} / \mathbf{L})\end{array}$ & $\begin{array}{l}\text { Percentage } \\
\text { of shoot } \\
\text { induction }\end{array}$ & $\begin{array}{c}\text { Number of } \\
\text { shoots per } \\
\text { explant }\end{array}$ & $\begin{array}{c}\text { Shoot } \\
\text { length }(\mathrm{cm})\end{array}$ & $\begin{array}{c}\text { Percentage of } \\
\text { shoot } \\
\text { multiplication }\end{array}$ & $\begin{array}{l}\text { Number of } \\
\text { shoots per } \\
\text { micro shoot }\end{array}$ & $\begin{array}{c}\text { Shoot } \\
\text { length }(\mathrm{cm})\end{array}$ \\
\hline MS-1 & 2.22 & - & $15.17 \pm 1.65^{\mathrm{a}}$ & $1.40 \pm 0.65^{\mathrm{a}}$ & $1.02 \pm 0.55^{\mathrm{a}}$ & $12.80 \pm 3.15^{\mathrm{a}}$ & $2.95 \pm 0.98^{\mathrm{a}}$ & $3.10 \pm 0.65^{\mathrm{a}}$ \\
\hline MS-2 & 4.43 & - & $27.67 \pm 4.52^{b}$ & $2.20 \pm 0.91^{\mathrm{ab}}$ & $1.34 \pm 0.42^{\mathrm{ab}}$ & $36.60 \pm 4.47^{b}$ & $7.93 \pm 1.13^{b}$ & $3.22 \pm 0.60^{\mathrm{a}}$ \\
\hline MS-4 & 8.87 & - & $57.50 \pm 6.81^{\mathrm{c}}$ & $3.40 \pm 0.84^{\mathrm{bc}}$ & $1.65 \pm 0.47^{\mathrm{abc}}$ & $46.00 \pm 5.65^{\mathrm{c}}$ & $16.10 \pm 1.91^{\mathrm{d}}$ & $4.92 \pm 0.79^{\mathrm{bcd}}$ \\
\hline MS-5 & 11.11 & - & $61.90 \pm 7.44^{\mathrm{c}}$ & $3.90 \pm 0.99^{\mathrm{bcd}}$ & $1.66 \pm 0.47^{\mathrm{abc}}$ & $57.70 \pm 5.41^{\mathrm{d}}$ & $19.50 \pm 3.37^{\mathrm{e}}$ & $4.93 \pm 0.62^{\mathrm{bcd}}$ \\
\hline MS-6 & 8.87 & 0.54 & $65.20 \pm 5.47^{\mathrm{cd}}$ & $4.30 \pm 1.49^{\text {cde }}$ & $1.82 \pm 0.61^{\mathrm{bc}}$ & $66.10 \pm 5.46^{\mathrm{e}}$ & $22.70 \pm 4.00^{\mathrm{ef}}$ & $4.61 \pm 0.85^{\mathrm{bc}}$ \\
\hline MS-9 & 11.11 & 1.07 & $81.40 \pm 8.70^{\mathrm{f}}$ & $6.00 \pm 1.63^{\mathrm{e}}$ & $2.31 \pm 0.71^{\mathrm{c}}$ & $83.70 \pm 9.59^{f}$ & $24.20 \pm 3.85^{\mathrm{f}}$ & $6.02 \pm 0.64^{\mathrm{e}}$ \\
\hline \multicolumn{3}{|l|}{ F-value } & 127.110 & 14.475 & 4.89 & 149.343 & 79.573 & 21.563 \\
\hline \multicolumn{3}{|l|}{ P-value } & 0.00 & 0.00 & 0.00 & 0.00 & 0.00 & 0.00 \\
\hline
\end{tabular}

Table 2: Effect of IBA on root induction

\begin{tabular}{|l|c|c|c|c|}
\hline Medium & $\begin{array}{c}\text { IBA } \\
(\mathbf{m g} / \mathbf{L})\end{array}$ & $\begin{array}{c}\text { Percentage of root } \\
\text { induction }(\%)\end{array}$ & $\begin{array}{c}\text { Number of Roots } \\
\text { per shoots }\end{array}$ & $\begin{array}{c}\text { Root length } \\
(\mathbf{c m})\end{array}$ \\
\hline MS-10 & 4.92 & $23.80 \pm 4.49^{\mathrm{a}}$ & $1.35 \pm 0.52^{\mathrm{a}}$ & $3.46 \pm 0.53^{\mathrm{a}}$ \\
\hline MS-11* & 4.92 & $59.70 \pm 5.85^{\mathrm{c}}$ & $2.50 \pm 0.81^{\mathrm{bc}}$ & $4.71 \pm 0.91^{\mathrm{b}}$ \\
\hline MS-12 & 9.84 & $54.40 \pm 5.98^{\mathrm{c}}$ & $1.70 \pm 0.82^{\mathrm{ab}}$ & $3.80 \pm 0.62^{\mathrm{a}}$ \\
\hline MS-13* & 9.84 & $75.70 \pm 7.42^{\mathrm{d}}$ & $2.90 \pm 0.99^{\mathrm{c}}$ & $4.99 \pm 0.58^{\mathrm{b}}$ \\
\hline MS-14 & 14.76 & $48.80 \pm 5.55^{\mathrm{b}}$ & $2.10 \pm 0.99^{\mathrm{abc}}$ & $4.95 \pm 0.83^{\mathrm{b}}$ \\
\hline MS-15* & 14.76 & $84.00 \pm 6.14^{\mathrm{e}}$ & $4.50 \pm 1.08^{\mathrm{d}}$ & $5.45 \pm 0.83^{\mathrm{b}}$ \\
\hline \multicolumn{2}{|c|}{ F-value } & 126.686 & 15.80 & 10.828 \\
\hline \multicolumn{2}{|c|}{ P-value } & 0.00 & 0.00 & 0.00 \\
\hline
\end{tabular}

Note: * Half strength MS medium.

The values represent the Mean \pm SD of ten replicates and all experiments were repeated thrice, mean difference of significant is at the 0.05 level. Means with different letter within column are significantly different from each other at $\mathrm{P} \leq 0.05$. 